\title{
Surgical management of hiatal herniae and oesophageal strictures in systemic sclerosis
}

\author{
R. H. F. B R A I N \\ Guy's Hospital, London
}

\begin{abstract}
Brain, R. H. F. (1973). Thorax, 28, 515-520. Surgical management of hiatal herniae and oesophageal strictures in systemic sclerosis. The clinical manifestations of 10 patients with systemic sclerosis whose oesophageal complications were managed by surgery are reported. Ninety per cent had a severe ulcerating type of oesophagitis and all had hiatal herniae demonstrable by contrast radiology. All but two had fibrous strictures.

Their treatment by surgery is reviewed. Earlier diagnosis of reflux oesophagitis should be beneficial in leading to successful control by a simple hiatal hernia repair. The severity of the oesophagitis is explained. Stricture formation, when present, should be treated by excision with replacement by jejunum or colon before the cardiopulmonary manifestations of the disease preclude major surgical measures.

The finding of an impaired vagal neurological supply to the oesophagus in the form of a deficiency in Auerbach's ganglion cells in two patients is of interest. Reflux oesophagitis is classified.
\end{abstract}

Systemic sclerosis is a bizarre progressive disease responsible for a number of well-recognized clinical syndromes which depend upon its distribution. All are agreed that there is a collagen fault of connective tissue and smooth muscle. The viscera, in particular the oesophagus, the peripheral blood vessels, and lungs, appear to be the areas most often affected.

Involvement of the oesophagus, first reported in 1903 by Ehrmann, is now recognized by its progressive dilatation with poor or absent peristaltic activity and atrophy of the wall. Dilatation was recorded by Rake (1931). An association with gastro-oesophageal reflux was first pointed out in 1943 by Lindsay, Templeton, and Rothman and a high incidence of associated hiatal hernia by Olsen, O'Leary, and Kirklin (1945). Not all writers on this subject are agreed; Somerville, Bargen, and Pugh (1959) found hiatal herniae in only two of their 11 patients while Hale and Schatzki (1944) did not mention such an association.

The objects of this paper are to present 10 personal cases of clinically diagnosed systemic sclerosis (all were females and suffered from dysphagia, an associated reflux oesophagitis, and hiatal herniae) and to discuss the management of these patients by surgery. In terms of the incidence of hiatal herniae the disparity between this and other series may be due to the manner in which the cases present. All patients in this personal group, although subsequently found to be suffering from systemic disease, were originally referred to me solely as cases of dysphagia.

\section{CLINICAL FEATURES}

The clinical features of the patients in the series are recorded in Tables $I$ and II.

Table I demonstrates the generalized nature of their disease. All had skin and peripheral vascular disease, while six patients in the group had lung involvement causing progressive dyspnoea. One patient had calcification in the lung fields, and in the four patients who died, lung changes appeared to have been the principal cause of death.

Table II summarizes the important oesophageal findings. In most patients the peripheral vascular and skin signs preceded a long history of dysphagia. All had demonstrable hiatal herniae seen by both radiologist and oesophagoscopist. In all but two cases a fibrous stricture was found in association with an ulcerating type of oesophagitis (grades III to IV). An associated congenital short type of oesophagus with a squamous columnar epithelial junction at $32 \mathrm{~cm}$ coinciding with a stricture was found in case 9. Diagnoses were made largely on the barium swallow studies; these showed poor or absent primary peristaltic waves 
T A B LE I NON-OESOPHAGEAL CLINICAL FEATURES

\begin{tabular}{|c|c|c|c|c|c|c|c|c|c|c|}
\hline \multirow{2}{*}{ Case } & \multirow{2}{*}{$\begin{array}{c}\text { Age at } \\
\text { Operation } \\
(y r)\end{array}$} & \multirow{2}{*}{$\begin{array}{c}\text { Total } \\
\text { Duration } \\
\begin{array}{c}\text { Symptoms } \\
(\mathrm{yr})\end{array}\end{array}$} & \multicolumn{3}{|c|}{ Skin Signs } & \multirow{2}{*}{$\begin{array}{c}\text { 'Rheumatoid' } \\
\text { Joints }\end{array}$} & \multicolumn{3}{|c|}{ Peripheral Vascular } & \multirow{2}{*}{$\begin{array}{c}\text { Lung } \\
\text { Signs } \\
\text { /Symptoms }\end{array}$} \\
\hline & & & Sclerosis & Calcification & Telangiectases & & $\begin{array}{l}\text { Acro- } \\
\text { sclerosis }\end{array}$ & $\begin{array}{l}\text { Raynaud's } \\
\text { Phenomena }\end{array}$ & $\begin{array}{l}\text { Ulcera- } \\
\text { ation }\end{array}$ & \\
\hline 1 & 37 & 20 & $+t+$ & $++t$ & + & ++ & ++ & ++ & ++ & $\begin{array}{c}++ \\
\text { with } \\
\text { calcification }\end{array}$ \\
\hline $\begin{array}{l}2 \\
3\end{array}$ & $\begin{array}{l}54 \\
61\end{array}$ & $\begin{array}{l}25 \\
25\end{array}$ & $\begin{array}{l}++ \\
++\end{array}$ & ++ & - & - & $+t$ & $\begin{array}{l}+t \\
++\end{array}$ & + & + \\
\hline 4 & $\begin{array}{l}01 \\
57\end{array}$ & 6 & ++ & - & + & $\bar{t}$ & $\begin{array}{c}++ \\
+\end{array}$ & $\begin{array}{c}++ \\
+\end{array}$ & \pm & $+t$ \\
\hline 5 & 66 & 20 & +++ & $\stackrel{+}{+}$ & + & - & + & + & + & ++ \\
\hline 6 & 59 & 20 & + & $\begin{array}{c}\text { (Legs) } \\
+\end{array}$ & - & $\ldots$ & ++ & ++ & + & - \\
\hline 7 & 58 & 19 & +++ & - & - & + & + & + & + & - \\
\hline 8 & 44 & 21 & ++ & ++ & - & - & + & + & + & - \\
\hline 9 & 59 & 20 & + & - & - & - & + & + & - & ++ \\
\hline 10 & 48 & 9 & ++ & $+t$ & - & - & + & + & + & - \\
\hline
\end{tabular}

T A B L E I I

OESOPHAGEAL SYMPTOMS/SIGNS

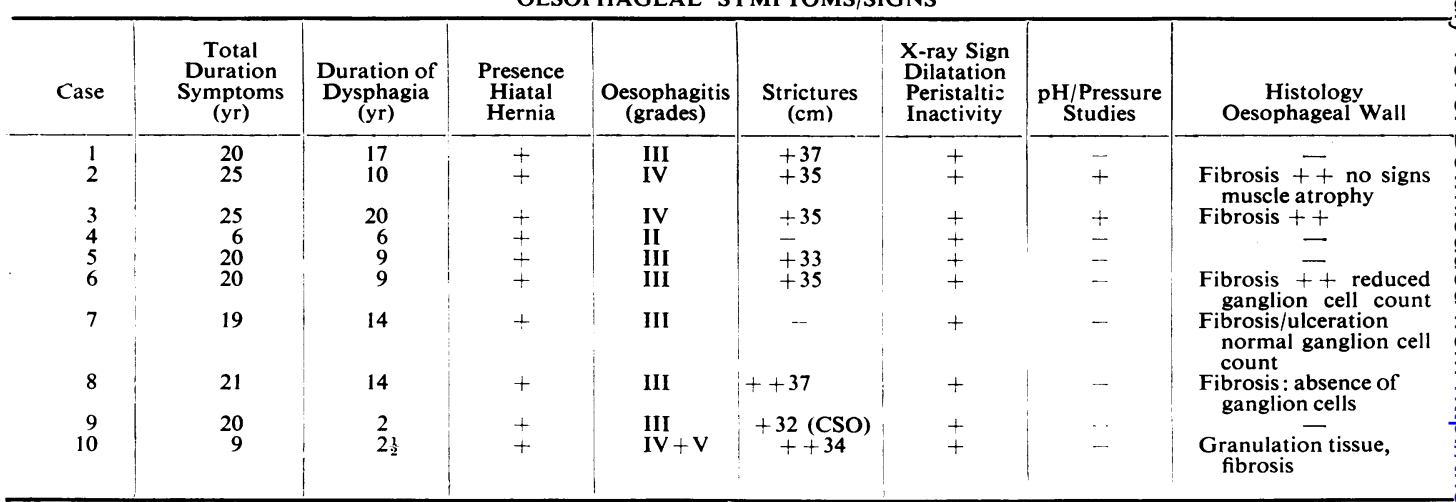

with dilatation of the oesophageal lumen. Previously reported difficulties arising through confusion between these cases and those showing diffuse oesophageal spasm were not experienced. Oesophagometry studies, recognized as an improved diagnostic procedure by Creamer, Andersen, and Code (1956) and later confirmed by Atkinson and Summerling (1966), were performed in only two patients in the series when they were combined with $\mathrm{pH}$ studies confirming reflux from the stomach.

\section{SURGICAL MANAGEMENT}

Table III sets out the surgical experience of this small group of patients. It fairly represents the wide variety of opinion still prevalent among surgeons as to the management of reflux oesophagitis. A gastric resection in case 5 and a vagotomy-gastric drainage operation in case 2 both failed to control progressive stricture formation. Neither operation controls reflux and may aggravate the condition by causing damage to the sensitive cardiac mech-oanism, possibly with resultant alkaline trypsin reflux from the small intestine, the effect of which on the oesophagus is far worse than that of gastric juice.

Mis-diagnosis resulted in cardiomyotomies being

T A B L E I I I

SURGICAL MANAGEMENT

\begin{tabular}{|c|c|c|c|}
\hline For relief of & & Patients & Cases \\
\hline \multirow{2}{*}{$\begin{array}{r}\text { Oesophagitis } \\
\text { /dysphagia }\end{array}$} & Repair hiatal hernia & 6 & $2,4,6,7,8$ \\
\hline & $\begin{array}{l}\text { Replacement operations } \\
\text { Jejunum } \\
\text { Colon } \\
\text { Cardiomyotomy } \\
\text { Partial gastrectomy } \\
\text { Vagotomy/pyloroplasty } \\
\text { Bouginage } \\
\text { Gastrostomy }\end{array}$ & $\begin{array}{l}3 \\
1 \\
2 \\
1 \\
1 \\
3 \\
1\end{array}$ & $\begin{array}{l}2,3,6 \\
10 \\
3,10 \\
5 \\
2 \\
1,5,6\end{array}$ \\
\hline Vascular & Sympathectomy & 4 & $1,2,5,10$ \\
\hline Others & $\begin{array}{l}\text { Partial thyroidectomy } \\
\text { (Hashimoto) } \\
\text { Radical mastectomy }\end{array}$ & $\begin{array}{l}1 \\
1\end{array}$ & $\begin{array}{l}2 \\
6\end{array}$ \\
\hline
\end{tabular}


T A B L E I V

RESULTS OF SURGERY

\begin{tabular}{|c|c|c|c|c|c|c|}
\hline Case & Cortisone & & & & & \\
\hline 1 & + & Dilatations & Moderate symptomatic relief & Died & $20 \mathrm{yr}$ & Cardiorespiratory \\
\hline 2 & + & 'Jejunal' transplant 1961 & $\begin{array}{l}\text { Complete and permanent relief } \\
\text { Fluids only preoperation }\end{array}$ & Died & 9, & Cardiac failure \\
\hline 3 & - & 'Jejunal' transplant 1961 & $\begin{array}{l}\text { Good result } 5 \text { yr, deterioration moderate } \\
\text { dysphagia (normal food) }\end{array}$ & Alive and well & 10 & \\
\hline 4 & + & Repair hiatal hernia 1963 & $\begin{array}{l}\text { Complete relief oesophagitis but moderate } \\
\text { dysphagia on normal food }\end{array}$ & Died & 6 & $\begin{array}{l}\text { Cardiorespiratory } \\
\text { failure }\end{array}$ \\
\hline 5 & + & $\begin{array}{l}\text { Dilatations (3) } \\
\text { Gastrostomy } 1964\end{array}$ & Slight symptomatic relief & Died & 2, & $\begin{array}{l}\text { Cardiorespiratory } \\
\text { failure; wasting }\end{array}$ \\
\hline 6 & - & 'Jejunal' transplant 1966 & $\begin{array}{l}\text { Complete relief all symptoms plus } 1 \text { st } \\
\text { weight; fluids only preoperation }\end{array}$ & Alive and well & 6, & \\
\hline 7 & + & $\begin{array}{l}\text { Repair hiatal hernia } \\
1967\end{array}$ & $\begin{array}{l}\text { Incomplete relief, normal food slowly }+1 \frac{1}{2} \\
\text { st weight, fluids only preoperation }\end{array}$ & Alive and well & & \\
\hline 8 & - & $\begin{array}{l}\text { Repair hiatal hernia } \\
1968\end{array}$ & $\begin{array}{l}\text { Incomplete relief }{ }^{1} \text {-normal food slowly } \\
\text { moderate persistent stricture }\end{array}$ & Alive and well & 4, & \\
\hline $\begin{array}{r}9 \\
10\end{array}$ & $\overline{-}$ & $\begin{array}{l}\text { Repair hiatal hernia } 1969 \\
\text { 'Colon' transplant } 1970\end{array}$ & $\begin{array}{l}\text { Incomplete relief of symptoms }{ }^{2} \\
\text { Complete relief all symptoms, fluids only } \\
\text { preoperation }\end{array}$ & $\begin{array}{l}\text { Alive and well } \\
\text { Alive and well }\end{array}$ & 2, & \\
\hline
\end{tabular}

Advised to have transplant but refused-satisfied with improvement

2Transplant advised but unfit-cardiopulmonary reasons
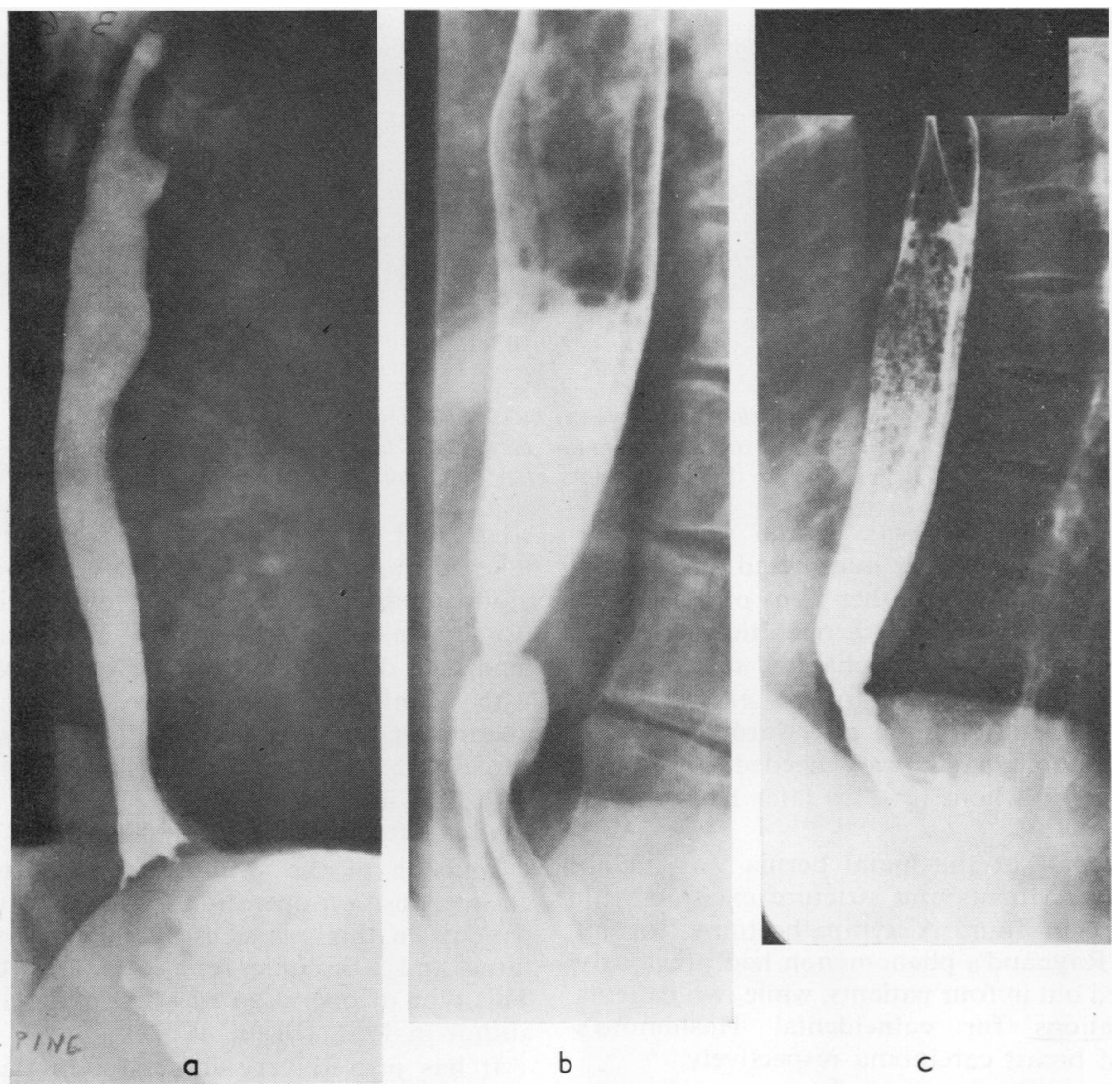

$\omega$

○

合

FIG. 1. Case 8 (a). Barium study 1961 shows reflux but no definite hiatal hernia. (b) Six years later-an obvious hiatal hernia and stricture. (c) Two years after hiatal hernia repairimprovement only. 


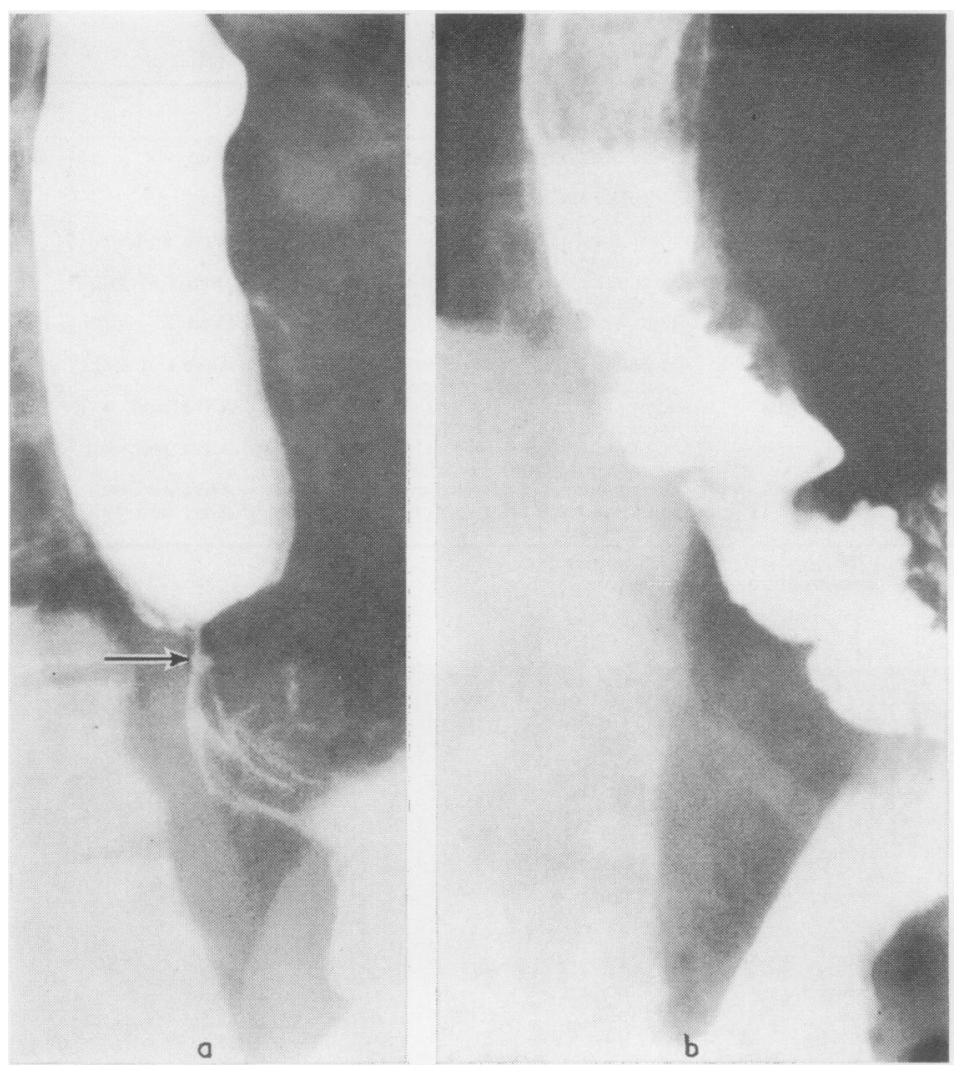

FIG. 2. Case 6. Barium swallows (a) in 1966, immediately before a jejunal transplant operation, showing a hiatal hernia and a tight stricture; (b) in 1972, six years after operation.

performed on two patients of the series, their radiological pictures being interpreted as showing achalasia at a time when other signs of a systemic sclerosis were minimal. These operations led to a rapid worsening of the oesophagitis, stricture formation, and the necessity for an excision and replacement operation soon afterwards.

Repeated bouginage was needed by three patients, one of whom (case 5) later had to have a gastrostomy.

Simple repair of the hiatal hernia was undertaken in five patients and stricture excision with replacement in four. A sympathectomy for an associated Raynaud's phenomenon had previously been carried out in four patients, while two patients had operations for coincidental Hashimoto's disease and breast carcinoma respectively.

\section{RESULTS OF SURGERY}

The detailed results are set out in Table IV. It can be seen that simple repair of the hiatal hernia was rather disappointing. In three of the four patients so treated, despite the patient's initial ability to take normal solids, where only fluids had previously been accepted, a mild dysphagia recurred usually taking the form of slow eating; this tended to deteriorate over the years. Two patients 윽 who have had repairs now require transplant $\rightarrow$ operations but one (case 8) has refused further surgery on the grounds that she is happy enough $N$ with her improvement (Fig. $1 \mathrm{a}-\mathrm{c}$ ). The other has lung function too poor for safety.

Excision of the stricture with replacement by $\mathrm{N}^{\mathrm{N}}$ an interposition operation was carried out in four patients in this series, using a jejunal segment in three and a colonic replacement in the fourth. This type of operation was first undertaken by the ? author in 1951 (Brain, 1967).

It has proved very successful in this series in $\frac{\vec{O}}{\vec{D}}$ that three of the four patients have had permanent $\stackrel{?}{\stackrel{\rho}{\odot}}$ and complete relief of all their oesophageal $\stackrel{\AA}{\varrho}$ symptoms (Fig. $2 \mathrm{a}$ and $\mathrm{b}$; Fig. $3 \mathrm{a}-\mathrm{c}$ ). One died after nine years from myocardial failure; two 8 

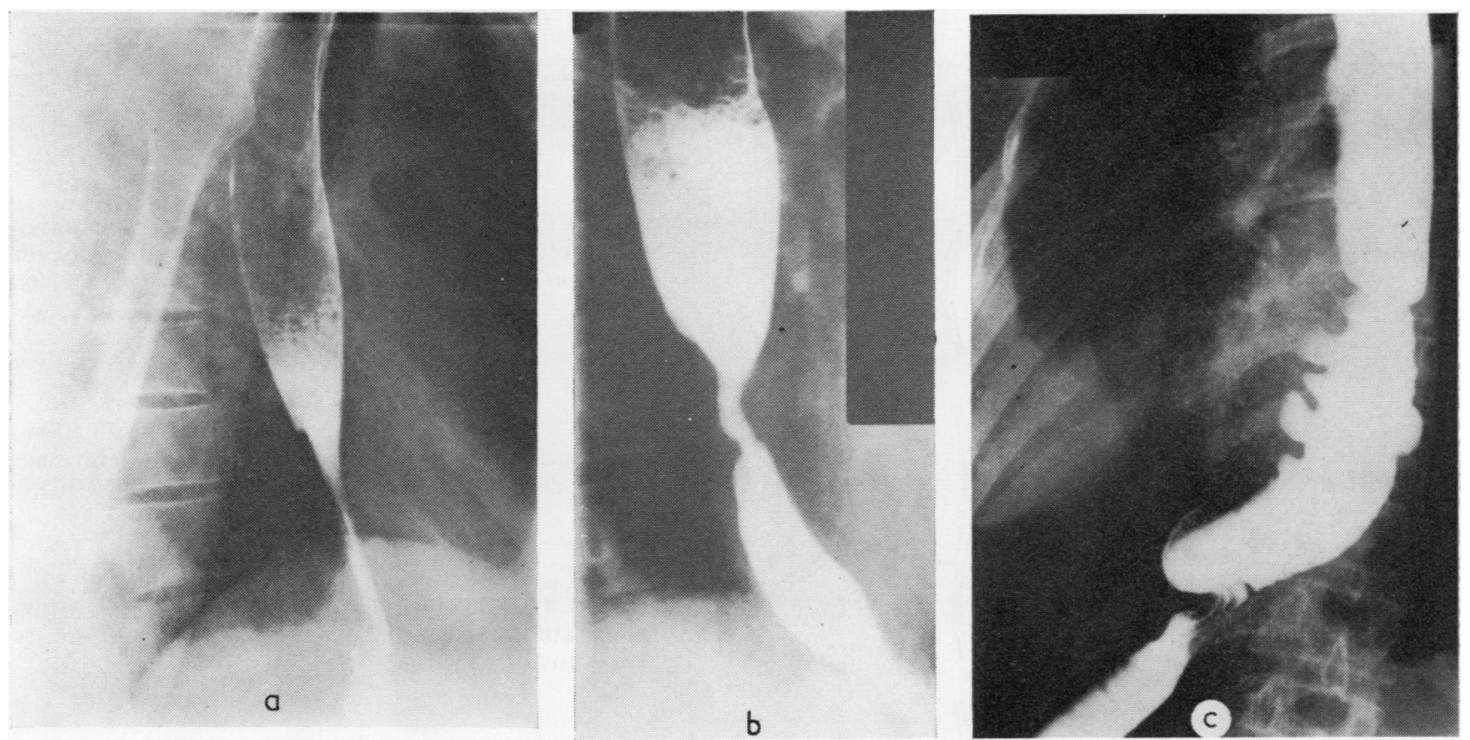

FIG. 3. Case 10. Barium swallows (a) before the original operation-a cardiotomy; (b) one year later, showing rapid deterioration after cardiotomy with peptic stricture formation and a large hiatal hernia; (c) one year after a colon interposition operation.

others are well after six years and two years. The remaining patient 10 years after a jejunal interposition operation has deteriorated during the past five years with a mild recurrence of dysphagia in association with increased dilatation of the oesphagus above the transplant; she can swallow normal food slowly.

There have been no operative deaths. The only postoperative complication was a large intrapleural haematoma in case 10 which became infected and had to be drained.

\section{DISCUSSION}

A feature of systemic sclerosis affecting the oesophagus is its close association with gastro-oesophageal reflux and hiatal hernia. Which is the primary change and whether it is possible for the former to occur without the latter is speculative. A partial explanation is available for reflux if one accepts smooth muscle atrophy of the lower oesophagus as an early feature of its involvement by the disease ; this could lead to a loss of the intrinsic oesophageal sphincter believed by many to play an important role in the general mechanism whereby the cardia controls reflux. Once free reflux is promoted in an oesophagus already rendered hypersensitive to the effects of intestinal juice by virtue of its poor ability to contract propulsively, it seems likely that a severe ulcerative type of oesophagitis will arise. Such an oesophagitis is likely to result in progressive fibrosis with shortening of the oesophagus, early aggravation of the pyrosis, and later dysphagia.

Support for such a sequence of events can easily be found in this series; $90 \%$ of the patients had an oesophagitis of the severe ulcerating type-grades III, IV, and V (author's classification, Table V).

It may be significant that the only patient whose repair was permanently successful (case 4) had preoperative oesophagitis of grade II with minimal fibrosis and shortening. If these patients were considered earlier for a simple repair of their hiatal herniae the permanent success rate might be higher.

It seems that a logical solution to the stricture problem in these patients would be earlier excision, with refashioning operations using either jejunum or colon. Delay in such a progressive disease may produce patients who are too ill for surgery due to their cardiopulmonary complications (cases 5 and 9).

Considering the likely aetiology of the pathological changes found in the oesophagus, the Auerbach's ganglion cell counts performed in cases 6,7 , and 8 should be mentioned. One of them was normal, one showed a complete absence, and the third a very much reduced count. In contrast, Atkinson and Summerling (1966) investigated the histological pattern of their 22 patients and found in each a normal number of ganglion cells. 
T A B L E V

\section{Grade I}

Symptoms only - no change at oesophagoscopy

\section{GRADE II}

'Erythema' the only sign

\section{Grade III}

Ulceration-vertical serpiginous type extending upwards from cardia for a varying distance

\section{Grade IV}

Ulceration-continuous upwards, often with islets of squamous epithelium left behind and encircled by granulation tissue. An irregular junction zone with normal squamous epithelium

\section{Grade V}

Ulceration-additional 'penetrating' ulcer of the cardiac columnar epithelium - peri-oesophagitis, adhesions, and enlargement of the focal lymph glands

\section{REFERENCES}

Atkinson, M., and Summerling M. D. (1966). Oesophageal changes in systemic sclerosis. Gut, 7, 402.

Brain, R. H. F. (1967). The place for jejunal transplantation in the treatment of simple strictures of the oesophagus. Annals of the Royal College of Surgeons of England, 40, 100.

Creamer, B., Andersen, H. A., and Code, C. F. (1956), Esophageal motility in patients with scleroderma and related diseases. Gastroenterologia (Basel), 86, 763.

Ehrmann, S. (1903). Uber die Beziehung der Sklerodermie zuden autotoxischen Erythemen. Wiener medizinische Wochenschrift, 53, 1097.

Hale, C. H., and Schatzki, R. (1944). The roentgenological appearance of the gastrointestinal tract in scleroderma. American Journal of Roentgenology, 51, 407.

Lindsay, J. R., Templeton, F. E., and Rothman, S. (1943). Lesions of the oesophagus in generalized progressive scleroderma. Journal of the American Medical Association, 123, 745.

Olsen, A. M., O'Leary, P. A., and Kirklin, B. R. (1945). Esophageal lesions associated with acrosclerosis and scleroderma. Archives of Internal Medicine, 6, 189.

Rake, G. (1931). On the pathology and pathogenesis of scleroderma. Bulletin of the Johns Hopkins Hospital, 48, 212.

Somerville, R. L., Bargen, J. A., and Pugh, D. G. (1959). Scleroderma of the small intestine. Postgraduate Medicine, 26, 356. 